\title{
Entrevista de Mário CaImi aos Cadernos de Filosofia alemã
}

\author{
Por: Bruno Nadai \\ e Monique Hulshof
}

Professor da Faculdade de Filosofia e Letras da Universidade de Buenos Aires, Mario Caimi foi reconhecido pela Sociedade Kant Internacional como "um dos mais profundos e renomados pesquisadores atuais da filosofia de Kant", recebendo em 2010 o Premio Kant Internacional, homenagem que ocorre a cada cinco anos e já destacou a importância das obras de filósofos que se dedicam ao estudo da filosofia kantiana, como Dieter Henrich e Henry Allison. A trajetória internacional de Caimi começou a constituir-se com seu doutoramento na Universidade de Mainz, em 1982, adquirindo vigor através dos cursos ministrados, como professor convidado, em diversas universidades, dentre elas a Universidade de Paris I (França), a Universidade de Eichstätt (Alemanha) e as Universidades UFRGS e UFRN (Brasil). Pesquisador do CONICET (Consejo Nacional de Investigaciones Científicas y Técnicas) desde 1983, Caimi publicou diversos artigos e livros sobre a filosofia kantiana. Sua obra versa, em especial, sobre a filosofia teórica de Kant, destacando-se o esforço em compreender passagens difíceis da Crítica da razão pura, como a dedução transcendental e o esquematismo dos conceitos puros do entendimento. É notável, além disso, seu minucioso trabalho de tradução de várias obras de Kant para a língua espanhola, dentre as quais cabe ressaltar a relevância da nova tradução da Crítica da razão pura.

A entrevista foi organizada a partir de quatro blocos temáticos. No primeiro, de caráter biográfico, Caimi relembra alguns momentos importantes de sua formação intelectual, destacando seu interesse pela filologia e o estudo de línguas. No segundo bloco responde a questões teóricas, deixando clara uma compreensão do significado da metafísica que orienta sua interpretação da filosofia kantiana, tanto em seu viés teórico quanto em seu viés prático. No terceiro bloco tematiza o difícil trabalho de tradução 
e apresenta problemas de tradução de alguns termos de Kant. Por fim, reflete sobre algumas questões institucionais, como as relações entre as universidades e a recente organização para fundar a Sociedade Kant Ibero-americana.

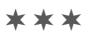

CFA: Em primeiro lugar, gostaríamos de agradecer a presença do senhor. Para nós, dos Cadernos de Filosofia Alemã, esta é uma oportunidade gratificante. Em segundo lugar, queremos parabenizá-lo pelo prêmio da Kant-Gesellschaft, que o senhor acaba de receber.

Caimi: Sou eu quem agradece pelo interesse de vocês.

CFA: Nossas perguntas foram divididas em diferentes blocos temáticos, e o primeiro deles é de caráter biográfico. A primeira questão que gostariamos de colocar é um pouco difícil para todos aqueles que estudam filosofia. De qualquer modo, gostariamos de perguntar o que levou o senhor a optar pelo estudo da filosofia?

Caimi: Trata-se de uma questão difícil, naturalmente, e que tem, talvez, infinitas respostas. $\mathrm{O}$ que me levou à filosofia? $\mathrm{O}$ destino, talvez. Mas lembro que uma vez, naqueles tempos difíceis da economia argentina, pedi a um amigo, que tem dinheiro e empresas, que me arrumasse um emprego. Ele então me disse que eu não servia para nenhuma outra coisa senão fazer filosofia. Talvez seja isso o que tenha me levado a estudar filosofia, não sei. Talvez eu já tivesse a cabeça disposta nesse sentido desde menino. Não sabia sequer que a filosofia existia, mas já estava pensando nessa forma de pensamento, nessa forma da mente.

CFA: Nesse sentido, o senhor destacaria alguma influência fllosófica que teria sido importante na sua formação, ainda no começo de sua vida universitária?

Caimi: Sim. Mas, antes, gostaria de dizer que, segundo penso, talvez não seja inteiramente exato tomar a Filosofia, a Filologia e a História como coisas separadas. Estas são divisões administrativas. Eu gostava de literatura em geral, do estudo das línguas e do pensamento teórico, não tinha uma influência definida. Fiquei 
maravilhado com todas essas coisas, naturalmente, e comecei a estudar grego, a ler Platão, etc. Tudo isso exercia em mim um grande fascínio, mas não consigo identificar uma influência específica. Eu poderia dizer que recebi mais influência do estudo das línguas do que dos sistemas, e sempre procurei trabalhar com textos cheios de sentido, em línguas que me traziam desafios. Pode-se dizer que tenho uma mentalidade filológica.

CFA: O que levou o senhor a fazer seu doutoramento na Alemanha? Como foi o processo de saída da Argentina e de ida para a Alemanba?

Caimi: Isso também não é tão apresentável quanto deveria ser. Começava então a ditadura na Argentina, eu estava numa situação econômica um pouco complicada porque tinha um trabalho ruim. Consegui então uma bolsa de estudos. Eu sabia que na Alemanha estava o centro da produção filosófica, o centro da história da filosofia em nossos tempos, e sempre estive de certo modo orientado para lá. Agarrei essa oportunidade com grande entusiasmo, mas não posso dizer que tenha sido uma decisão madura, tomada depois da consideração de vários fatores.

CFA: Mas o seu interesse pela fllosofia kantiana é anterior a esta fase de doutoramento na Alemanha?

Caimi: Sim, porque na Argentina tive professores que eram bons em filosofia kantiana. E também porque a filosofia kantiana tem aquela sistematicidade, aquela clareza conceitual - ainda que haja pessoas digam que não, que ela é uma filosofia obscura. Esse rigor conceitual foi para mim decisivo. Outras filosofias pareciam depender muito da interpretação do momento, do entusiasmo sentimental do leitor ou intérprete. Kant não. Kant diz as coisas com o mesmo rigor com que fala um físico ou um matemático. Claro, o meu pai era físico-químico e eu já tinha esse apreço pelo rigor científico.

CFA: E qual foi a importância do professor Gerhard Funke para a sua formação, levando em conta que o senhor tem um estilo voltado para a bistória da filosofia e que dá muita importância para a filologia, estilo semelhante ao do professor Funke? 
Caimi: Tenho uma grande dívida com o professor Funke. Ele foi meu orientador. Recebi dele uma ajuda generosa não apenas nas questões teóricas (seus conhecimentos eram imensos), mas ele fez tudo que estava a seu alcance para promover meu desenvolvimento profissional. Mas, do ponto de vista teórico, é preciso dizer que o professor Funke tinha uma inclinação pela filosofia política e pela filosofia prática de Kant, e eu não. No entanto, junto com o professor Funke estava o professor Rudolf Malter, que morreu no ano de 1995 e era um filólogo extraordinário. As interpretações da filosofia teórica de Kant feitas pelo professor Malter foram muito importantes para mim. Naturalmente, o professor Funke não desconhecia a história da filosofia e a história das interpretações da filosofia kantiana. Ele também tinha aquele jeito europeu de fazer filosofia kantiana, que consiste na forte consciência do passado, forte consciência dos grandes intérpretes - Hermann Cohen, Vaihinger e tantos outros que estão aí. Essa consciência da importância destes intérpretes exerceu em mim grande fascínio. Quando eu estudava em Buenos Aires, nos anos 70 do século passado - não sei se no Brasil a coisa também era assim -, nós tínhamos pouco conhecimento sobre os grandes intérpretes e eu sempre pensava "Como eles fazem isso?" "Como podem ser tão geniais esses grandes intérpretes contemporâneos de Kant (Paton por exemplo)?” Eu me perguntava “Como é que ele compreendeu tudo e eu não consigo compreender nada?". Eu não entendia como isso era possível e me dizia: "Talvez ele seja genial, e eu um estúpido". Quando cheguei à Alemanha percebi que havia nas bibliotecas grandes estantes de pequenos trabalhos sobre conceitos, sobre, por exemplo, o conceito de coisa em si, o conceito de juízo, etc. Compreendi, então, que Paton não tinha tirado do nada todo seu trabalho de interpretação - o que não quer dizer que ele não seja genial -, mas pôde se apoiar em todos aqueles que vieram antes e fizeram um trabalho miúdo de interpretar um conceito, uma pequena parte do sistema. Ele se aproveitou obviamente de tudo isso. Para mim, isso foi uma grande revelação e, então, eu disse a mim mesmo: "Claro! Aqui devo ficar", pois é assim que se deve trabalhar, com o apoio das gerações que nos precederam. Esta revelação foi decisiva para mim, e foi o que fiz daí em diante. 
CFA: Em seu artigo "Adorno sobre as águas", a partir de uma leitura do "Ensaio como forma" e da Dialética Negativa, o senhor reflete sobre o problema do método da filosofia. O senhor defende que, enquanto as ciências teóricas possuem certa objetividade, na medida em que se circunscrevem dentro de limites, o método filosófico teria de comportar uma subjetividade - uma incompletude essencial - na medida em que o esforço filosófico coloca-se fora de qualquer limite traçável (a filosofia pergunta pelo suprassensivel, pelo incondicionado, pelo absoluto). Nessa medida, o ensaio teria sua aplicação própria na metafísica. Como o senhor compreende hoje a relação entre filosofia, metafísica e exposição?

Caimi: Esta é uma boa pergunta. $\mathrm{Na}$ primeira pergunta me indagaram sobre o que, inicialmente, me teria levado ao estudo da filosofia; esta é a mesma pergunta. Muitos anos depois de começar a estudar filosofia, muitos anos mesmo, quando eu completava 60 anos de idade, compreendi que a filosofia é precisamente aquele esforço para compreender o sentido da existência, o sentido do universo. Ela é precisamente isso, e não apenas um trabalho filológico. Mesmo se aceitarmos os limites que Kant impõe à pesquisa filosófica, descobriremos (e isso também no próprio Kant) que toda a Crítica da razão pura dirige-se a explicar as possibilidades da razão de alcançar essa compreensão. Como procurar o conhecimento do sentido do universo? Como procurar a sabedoria? É isto o que busca Kant na Crítica, e é isto que procuram os filósofos em geral. A filosofia tem, então, uma relação inseparável com a metafísica. Por isso é preciso também deixar aquelas aberturas, como eu dizia nesse artigo: deixar aquelas portas para além dos limites. Não sabemos nada além dos limites do conhecimento, mas temos de saber pelo menos que os limites não são absolutos, que eles não são tudo e que há algo mais que não podemos alcançar.

Mas nesse trabalho "Adorno Sobre as águas" - do qual fiz também uma versão ampliada em alemão - eu queria dizer também algo sobre a interpretação, porque há aí uma coisa um pouco misteriosa e que não sei se vou poder explicar claramente. Eu descobri experimentalmente, por tratar com estudantes, que cada um tem uma inteligência diferente e que a verdade não é uma única - contra Descartes. Descobri que cada um encontra um teto, um limite, segundo a inteligência que tem (não apenas segundo a 
quantidade, mas também segundo a qualidade da inteligência que tem). Era isso que eu queria assinalar nesse trabalho sobre Adorno, porque eu penso que deveríamos fazer justiça também a esta determinação da verdade segundo a inteligência. É uma maneira de dizer que o espírito sopra onde quer, como afirma o Evangelho. Ou seja, estamos sujeitos àquele sopro do espírito que vem ou não vem. E, quando vem, devemos aceitá-lo e escrever pacificamente tudo aquilo que recebemos nesse momento de inspiração. $\mathrm{E}$ assim devemos aceitar, pacificamente, as determinações e peculiaridades da inteligência pessoal de cada um, que levam cada um a perceber aquilo que só ele pode perceber e lhe impedem de perceber outras perspectivas. Porque há também esse momento quase não racional do trabalho filosófico. Não consigo explicar melhor, mas isso está aí, é um fato. Precisamente, aquela "incompletude essencial" é também um momento de modéstia para dizer "Isto é o que posso fazer segundo a quantidade e qualidade da inteligência que tenho". Não vou dizer "Isto é a verdade definitiva", mas estarei aberto para que talvez amanhã venha um momento de inspiração, como acontece todo tempo, no qual percebo que ontem estava errado e que hoje estou um pouco mais perto da verdade.

CFA: Mas existe uma verdade da qual possamos nos aproximar?

Caimi: Podemos dela nos aproximar infinitamente, e devemos fazê-lo. Devemos aceitar a variedade dos pontos de vista, porque cada um deles traz uma aproximação à verdade. O que podemos fazer, como Adorno, é esforçar-nos sinceramente para dizer o melhor que podemos dizer, sabendo que o melhor que podemos dizer é sempre limitado, é sempre segundo uma inteligência que tem um limite, um teto de desenvolvimento - o que acontece não só conosco, mas também com os demais, com os grandes intérpretes também.

CFA: A exposição, então, é sempre um processo, sempre uma construção de pensamentos?

Caimi: Sim. Isto poderia ser uma coisa desalentadora, porque poderíamos concluir que não devemos fazer mais filosofia porque não chegaremos a lugar algum. Mas não é assim, porque este fa- 
zer, este desenvolvimento da inteligência, é também um trabalho positivo. Por isso é um erro dizer que o artista não vai fazer nunca a obra definitiva, última. Ele na verdade não quer fazê-lo, quer apenas fazer obras preciosas, bonitas, o melhor que ele pode fazer. $\mathrm{E}$ as obras ficam aí, não se destroem todas as anteriores apenas porque as posteriores são também belas.

CFA: No artigo "Über eine wenig beachtete Deduktion der regulativen Ideen", o senhor mostra que não haveria duas concepçóes inconciliáveis de ideia na Crítica da razão pura, pois a concepção de ideia como "sentido de direção" exigiria a concep̧̧ão de ideia como um "quase-objeto" enquanto esquema, a qual possibilita a aplicação de regras pensadas como "sentido de direção". Como o senhor indica, esta função regulativa das ideias é retomada por Kant na segunda parte do "Apêndice à dialética transcendental" da primeira Crítica, onde ele se ocupa de mostrar o quanto é preciso manter da intenção especulativa contida nas ideias (intenção esta que seria inescapável, já que deriva da disposição natural da razão para a metafísica). Ora, segundo Gerard Lebrun em seu livro Kant e o fim da metafísica, esta quebra ou dualidade na concepção de ideia da primeira Crítica teria levado Kant a um deslize metafísico no "Apêndice". Para corrigir esse deslize teria sido escrita a Crítica da faculdade do juízo, em particular sua Primeira Introdução. Só então Kant teria cumprido o que para Lebrun seria o programa da filosofia critica: dar cabo da metafísica. De que modo o senhor se posiciona em relação à questão de uma metafísica kantiana?

Caimi: $\mathrm{O}$ primeiro grande trabalho de tradução que fiz foi de um texto kantiano póstumo, Os Progressos da metafísica. Traduzindo este texto, fiquei também deslumbrado, pois Kant está nele falando de metafísica mesmo, de modo que talvez se possa dizer que os grandes intérpretes do século passado estavam imbuídos demais da rejeição da metafísica, como é próprio da filosofia do final do séc. XIX e começo do séc. XX. Talvez Kant não concordasse completamente com isso, porque ele escreve que seu interesse era também poder responder às questões da metafísica tradicional. Vamos morrer definitivamente ou não? Existe um Deus? É estranho que não se tenha desenvolvido esta possibilidade de interpretação da filosofia kantiana. Ou melhor, ela foi desenvolvida por Max 
Wundt e outros autores, mas não era a interpretação dominante. Eu fiquei tão interessado por esta possibilidade que pensei que é preciso manter ao menos o interesse pela metafísica, a consciência de que a ciência não é um absoluto. Mesmo quando os cientistas fazem ciência e dizem que não existe nada além do cérebro, e que toda aquela metafísica não importa - ou quando dizem que não existe nada mais do que o átomo e suas combinações -, eles estão fazendo uma metafísica de baixa qualidade. Kant, pelo contrário, afirmaria que não conhecemos, e nem podemos conhecer, nada além do cérebro, nada além dos átomos e suas combinações, mas, ao mesmo tempo, que devemos estar cientes de que estas questões estão rodeadas de uma dimensão para nós inatingível, inalcançável e devem, portanto, ser relativizadas. Uma metafísica kantiana me parece ser esta relativização, esta prudência em não falar de tais questões em termos absolutos.

CFA: Mas a que o senhor atribuiria esta, digamos, desatenção dos intérpretes do começo do século XX com relação à metafísica kantiana, ou ainda, por que teria sido vencedora naquele periodo a interpretação de Kant como um destruidor da metafísica e não o contrário?

Caimi: Há muitas e diferentes respostas a esta pergunta. Naturalmente, se eu soubesse muito sobre a história da ciência na época poderia dizer, por exemplo, que a ciência teve nesse momento um desenvolvimento tão grande que deslumbrou até mesmo os intérpretes de Kant, de tal modo que eles ficaram também presos ao interesse pela ciência e descuidaram desse outro aspecto da filosofia kantiana. Mas há também outras questões interessantes. Por exemplo: mesmo se isso for verdade, por que não interessaria mais a nós a questão da imortalidade? Aceitamos de bom grado que vamos morrer? Parece que não nos importam mais todas aquelas demonstrações da imortalidade da alma, que podem até ser interessantes, mas por razões meramente filológicas. Não sei por que isso se dá. Talvez o desenvolvimento da humanidade implique que aceitamos de maneira madura o que em outros tempos era inaceitável. Para dizer em duas palavras: não sei. 
CFA: Ainda sobre Os Progressos da Metafísica, o senhor considera que nos Progressos Kant apresenta não um novo sistema metafísico, mas apenas uma nova maneira de colocar as questóes da metafísica clássica?

Caimi: Não estou completamente seguro disto. Talvez seja um novo quase-sistema. Kant afirma que os velhos sistemas eram incompletos, inviáveis ou não podiam funcionar, ele demonstra isso. Mas nem por isso ele afirma que devemos deixar isso tudo de lado e fazer apenas ciência. Ele nos convida a fazer ciência, mas uma ciência metafísica, a qual tem algumas condições que devemos aceitar. Por exemplo, há um fato completamente metafísico, como se Deus se fizesse presente aqui: o fato da consciência da lei moral. Não porque Kant seja um moralista, obsessivamente interessado pela moral, mas porque isso não é algo de relativo, é a presença do absoluto nas nossas vidas. E talvez a partir deste único fato absoluto que temos em nossas vidas se possa construir um mirante para olhar o que acontece no reino do absoluto, que não podemos alcançar de outro jeito. Por isso Kant constrói uma metafísica que é prática, de um lado, e dogmática, de outro. É uma nova combinação da razão teórica e da razão prática que dá lugar à metafísica kantiana.

Eu sustentei no meu comentário aos Progressos que devemos aceitar que se trata de uma nova metafísica, mas não apenas uma metafísica prática, porque para os fins da moralidade devemos apenas conhecer o dever e atuar segundo ele, enquanto Kant vai além disso ao afirmar que por conhecermos o dever conhecemos também um mandamento absoluto. Temos então o absoluto ao alcance da mão e, a partir daí, constrói-se não apenas uma teoria do dever, mas uma metafísica, uma teoria, uma metafísica teórico- prática, fundada nesse princípio prático.

CFA: Mas os objetos dessa nova metafísica, fundada na consciência absoluta do mandamento moral, serão, por coincidência ou não, os três objetos da metafísica clássica, não?

Caimi: Sim, porque Kant estava vivendo também numa época na qual esses objetos estavam presentes na consciência de cada um. Isto me lembra um livro de Cícero chamado De natura Deorum, 
no qual ele expõe a teologia dos estóicos dos tempos romanos. $\mathrm{O}$ que é interessante nesse livro é que os deuses passeiam no céu. $O$ Sol é um deus, as estrelas são deuses. Os deuses então estão aí, presentes na nossa vida, no nosso mundo. Isso é magnífico. Pensar que os deuses estão aí, ainda que não os compreendamos, leva a uma atitude, uma disposição pessoal, bastante peculiar. É isso que acontece com o Faktum da lei moral. O absoluto está aí. Mas também há um novo sentido para Deus, a alma e a imortalidade que se fazem presentes na realidade, no mundo do homem do séc. XVIII.

CFA: Nota-se, na sua prosução intelectual, um interesse especial por questões ligadas à filosofia teórica kantiana. No entanto, em Leçons sur Kant. La déduction transcendantale dans la deuxième édition de la Critique de la raison pure, o senhor recusa a interpretação epistemológica de Cohen (que considera a "Dedução Transcendental" como os fundamentos dos princípios sintéticos a priori da física). O senhor propóe que o objetivo da "Dedução" é o de "demonstrar que as categorias não são conceitos vazios e que elas se referem necessariamente a objetos existentes". Poderíamos chamar sua leitura de ontológica, ou metafísica, por oposição à vertente epistemológica? Se sim, em que sentido ela se distancia da leitura ontológica feita por Heidegger, em que a imaginação teria um papel essencial na "Dedução"?

Caimi: É preciso, antes de tudo, excluir o nome de Cohen das considerações feitas na pergunta, porque não tenho a coragem de me opor a ele. Eu recusei a interpretação epistemológica, mas Cohen é um grande mestre, ao qual não posso opor-me. Além disso, penso que a interpretação que defendi é metafísica, mas não ontológica. Como escrevi nessas "lições", temos na "Dedução Transcendental" uma renovação da pergunta de Parmênides sobre a relação entre o pensamento e o ser. Nela, Kant se coloca precisamente esta pergunta. Não se trata da mesma pergunta que se faz Heidegger ao propor que até mesmo o "eu" da "Dedução" seja temporal. Até onde consigo compreender, temos em Kant precisamente o contrário do que propõe Heidegger em sua leitura. Não pretendo me opor a Heidegger, ou dizer que ele não tem razão, porque esse meu livro é apenas o resultado de meu esfor- 
ço de compreensão e não me propus a fazer um grande trabalho que resolvesse todas as questões. Eu queria apenas compreender, e o que pude compreender da "Dedução" está lá exposto. Segundo entendo, é preciso que o "eu" não seja temporal e que haja uma oposição entre sensibilidade e entendimento, sendo que o "eu" tem de estar do lado do entendimento. Isso tudo é quase contrário ao que disse Heidegger. Em minha interpretação, a imaginação é uma variante do entendimento e o grande problema permanece: como fazer a conexão entre pensamento e ser. Naturalmente, não posso opor-me a Heidegger, não é essa minha intenção. É como disse Lutero, ao ser chamado pelo Imperador para esclarecer suas posições (que posteriormente levaram à guerra dos 30 anos) e expor - na dieta de Worms, se não me engano - sua interpretação do cristianismo, cunhando aquela frase famosa "Hier stehe ich und kann nicht anders! Gott helfe mir, Amen", isto é, "Aqui estou e não posso fazer outra coisa! Deus me salve, amém”. Não pretendo derrubar o grande Heidegger, ou ainda menos o grande Cohen, que para mim é ainda maior que Heidegger, mas trata-se do que pude compreender da "Dedução".

CFA: No XI Congresso Kant internacional de 2010, realizado em Pisa, o senhor buscou mostrar que o capitulo da Critica sobre o esquematismo não pode ser visto como uma mera continuidade em relação à "Dedução Transcendental", pois nele haveria um progresso da investigação em direção aos objetos da natureza - o que implica dizer, portanto, que haveria uma diferença entre o objeto enquanto tal, constituido pelo entendimento, e o objeto próprio à faculdade do juizo, que aplica as categorias aos fenômenos. Essas novas investigaçôes têm como intuito um aprofundamento da leitura "metafísica" comentada acima?

Caimi: Na verdade, busquei corrigir um pouco o que disse no livro, porque percebi que o ser não vem a nós senão em objetos sensíveis, empíricos. Tudo o que temos do ser são tais objetos. Compreendi então que na "Dedução" o objeto é igual a uma estrutura objetual, a síntese necessária de que fala Kant naquela passagem tão conhecida de A 104. A síntese que constitui o objeto é necessária e não apenas subjetiva e contingente. No entanto, no capítulo sobre o esquematismo muda-se o ponto de vista e o objeto passa a ser o 
objeto dado na sensibilidade, aquilo que aparece na sensibilidade. $\mathrm{O}$ eu, então, não tem nenhuma influência sobre esse aparecer, esse apresentar-se, essa presença. No objeto como produto das sínteses eu tenho mais do que influência, pois o "eu" é decisivo na constituição do objeto em geral, do objeto em sentido formal, daquilo que é a própria objetividade. Mas sobre a presença o eu não pode dizer nada, é simplesmente passivo; o sujeito simplesmente recebe algo na sensibilidade. Pensei então que aí se faz presente uma outra maneira de conceber o objeto. E deu certo: passei a compreender melhor o esquematismo. E compreender melhor é decisivo como prova de uma teoria, como disse Descartes nos Princípios de fllosofia (há uma bela tradução dos Princípios de Descartes na revista Analytica). Na última página dos Princípios, Descartes diz que, embora a melhor maneira de alcançar a verdade seja a dedução exata, por vezes não podemos deduzir exatamente. Nestes casos, podemos recorrer a uma teoria da interpretação que permite que os pedaços que devemos interpretar se encaixem, e isso pode ser uma prova suficiente da verdade. Para mim foi uma prova suficiente da verdade o fato de que consegui compreender melhor o capítulo sobre o esquematismo. Logo depois, em Pisa, o professor Hinske me disse que há dois livros que explicam exatamente o esquematismo. Um deles é o de Tetens, e o outro é a Metaphysica de Baumgarten. Neles, segundo Hinske, o esquematismo está explicado de maneira absolutamente transparente. Mas ainda não consegui encontrar essas passagens.

CFA: Ao lado de várias publicaçôes voltadas para a filosofia teórica de Kant, o senhor publicou também alguns artigos sobre filosofia prática, em especial sobre a filosofia politica kantiana. No texto intitulado "Acerca de la interpretacion del tercer articulo definitivo del ensayo de Kant Zum ewigen Frieden", o senhor propóe uma leitura do terceiro artigo definitivo de À Paz Perpétua, que pretende mostrar que é apenas como limitação do direito de hospitalidade que o terceiro artigo pode ser situado sistematicamente em relação aos Primeiros Princípios da Doutrina do Direito. De que modo o senhor entende a relação entre filosofia prática, filosofia politica e sistema na filosofia de Kant? Ou, dito de outro modo, qual seria o lugar sistemático da filosofia politica na obra kantiana? 
Caimi: Acho que não me aprofundei suficientemente na filosofia política para responder a esta pergunta. Penso que o lugar sistemático da filosofia política seja também um lugar dentro de uma estrutura geral daquela metafísica prático-dogmática, e a filosofia política seja apenas um momento para alcançar aquela ideia do homem, do homem moral, na qual se alcança de maneira completa o ideal da moralidade.

Há um biólogo alemão que diz que o elo perdido entre o animal e o homem somos nós. Penso que estamos a caminho de sermos homens. A filosofia política é uma descrição de algumas das condições que nos permitirão vir a ser homens.

CFA: O senhor diria que os procedimentos metodológicos utilizados pelo senhor para a busca da compreensão da filosofia teórica kantianaprocedimentos filológicos e históricos - são também adequados para uma compreensão sistemática da filosofia politica kantiana?

Caimi: Adequados sim, mas não suficientes. E por isso eu dizia que não sei se seria capaz de responder à pergunta anterior. São adequados, claro. Mas o tratado de Kant sobre a paz perpétua, por exemplo, é uma reação ao tratado de paz da Basiléia que se seguiu à guerra que opôs Áustria e Prússia, de um lado, e a França revolucionária, de outro. Se não se conhece adequadamente a história, não se será capaz de compreender adequadamente o escrito em questão. Ou seja, além dos conhecimentos filológicos, é preciso ter outros conhecimentos de que não disponho.

CFA: Haveria um conceito fundamental de sua obra?

Caimi: Não. Ela tem apenas a intenção de compreender um pouco melhor passagens obscuras, mas nem sequer de maneira sistemática. Se há alguma unidade sistemática eu não sei, é algo que talvez se possa ver de fora.

CFA: Para encerrar este bloco de questões teóricas colocamos mais uma pergunta. A sua abordagem da filosofia kantiana tem um caráter fortemente histórico. O senhor acredita ser possivel utilizar o pensamento de Kant para pensar problemas filosóficos contemporâneos? 
Caimi: O que vou dizer talvez seja um pouco arriscado, mas pergunto: Existem problemas filosóficos contemporâneos? Há problemas filosóficos, simplesmente. $\mathrm{Na}$ verdade, não me aprofundei muito na filosofia contemporânea.

CFA: Ora, poderiamos dizer que há dois problemas contemporâneos que por vezes se transformam em questóes filosóficas, o racismo e o feminismo. Em Pisa, no último Congresso da Kant-Gesellschaft, foram apresentadas conferências que discutiam o problema das diferentes raças humanas no pensamento de Kant. Há vários intérpretes na KantForschung que colocam questões dessa ordem.

Caimi: Sim, é verdade. Mas não sei se isso é uma questão de interpretação da filosofia de Kant ou do seu aproveitamento, o que precisa ser diferenciado. Se pegarmos textos de Kant sobre feminismo, ou sobre racismo, veremos coisas não muito agradáveis. Mas, por outro lado, se pegarmos textos de Kant que não sejam sobre questões históricas ou circunstanciais, mas sobre o homem em geral, sobre o que deve ser, sobre a filosofia prática, etc., então veremos que Kant tem muitas coisas a dizer que não são rejeitáveis, mas, pelo contrário, são bastante aceitáveis. Esta dupla posição é também uma dupla avaliação que temos de fazer dos textos de Kant. Há textos de Kant que são circunstanciais, ditados pelas circunstancias e preconceitos de Kant - porque ele estava vivendo num dado tempo e espaço. Mas há outros textos em que Kant escapa das determinações do tempo e espaço em que vivia e consegue fazer filosofia em sentido próprio; são verdades universais que não são válidas apenas num momento e lugar. Quando consegue fazer isso, quando faz filosofia, Kant diz coisas que são muito interessantes, e até verdadeiras para nós, para pensar problemas como o do feminismo e do racismo.

Uma vez eu estava num congresso na Alemanha e um senhor se dirigiu a mim e me perguntou como eu, uma pessoa vinda da América do Sul, um desses lugares esquecidos por Deus, podia ousar falar de Kant se nem sequer possuía a linguagem apropriada (na verdade eu tenho a linguagem, meu alemão é muito melhor do que o meu português, mas sou um estrangeiro). Ele me disse que os verdadeiros intérpretes de Kant deveriam ser apenas aqueles 
que têm a língua alemã como língua materna. Isto é um erro, é compreender mal Kant.É como se disséssemos que o pobre Kant trabalhou, trabalhou e não conseguiu fazer uma filosofia válida universalmente, mas válida apenas para alemães. No entanto, o que Kant queria fazer é o que todos os filósofos pretendem fazer, uma filosofia universal, para os homens em geral, e nem sequer apenas para os homens, mas propriamente universal, assim como o matemático faz matemática não apenas para os homens, mas universalmente. Naturalmente, com essas pretensões imensas, por vezes o filósofo consegue fazer apenas umas poucas linhas de filosofia. E todo o resto é intenção não cumprida, não realizada. Mas o que vale é o que é universal.

CFA: A respeito da questão de se haveria ou não problemas filosóficos contemporâneos, gostariamos de formular a seguinte questão. De fato, um problema filosófico que se torna mais agudo na contemporaneidade, dentre outros tantos, diz respeito à convivência de diferentes cidadãos numa determinada comunidade politica quando não há mais uma concep̧̧ão moral abrangente que possa unificar as diferentes concepçöes particulares de bem e de vida boa. Pode-se dizer que este é um problema que de certo modo já estava posto para a filosofia clássica grega, por exemplo, mas que na sociedade contemporânea se torna mais agudo - vide a Alemanha com seus problemas de integração entre cidadãos alemães nascidos de pais alemães e cidadãos alemães nascidos de pais turcos. Embora o senhor tenha dito que as suas reflexões não dedicam a mesma atenção à filosofia prática e à filosofia teórica de Kant, de que modo o senhor avalia o recurso de certos filósofos contemporâneos à filosofia prática kantiana para pensar problemas como estes? Referimonos em particular à apropriação da filosofia kantiana feita por filósofos como Habermas e Rawls.

Caimi: Numa resposta perspectivista, segundo meus interesses pessoais, eu diria que eles fazem bem em aproveitar aquelas coisas que Kant oferece para tratar diferentes problemas. Mas Kant vai bem mais longe do que isso, porque ele é um pouco mais cético, quiçá mais prudente, mais rigoroso. Kant não procura aplicar os conceitos diretamente para a resolução de problemas. Ele é bem consciente de que problemas como esses não têm uma solução 
apenas filosófica. Eu, pessoalmente, estou interessado nos problemas verdadeiramente filosóficos, teóricos, e a distância em relação aos problemas reais da política é aí imensa. Quer dizer, Kant naturalmente afirma que há tais problemas, e que é preciso sabedoria para saber fazer concordar todos os fins particulares num fim geral, absoluto, universal. Mas a sabedoria é algo que se tem de perseguir infinitamente e, afinal, quando Kant se vê obrigado a dizer o que podemos possuir da sabedoria, ele afirma que podemos saber apenas duas coisas: a indicação "cumpre o teu dever"; e a indicação "faz-te digno da felicidade". São indicações bem pequenas, porque ele sabe bem que sobre isso não é possível fazer indicações mais exatas sem sair da filosofia universal e avançar para o terreno da aplicação, onde entram muito mais fatores do que pode trabalhar um filosofo interessado na filosofia pura. Como vamos trabalhar com os preconceitos de pessoas que dizem que são melhores do que outras? Isto é uma questão mais psicológica e histórica do que filosófica.

CFA: O senhor possui várias publicações de traduções, dentre as quais cabe destacar a recente tradução da Crítica da razão pura, a qual, entre outras coisas, conta com uma grande compilação de termos para várias linguas. Como encara o trabalho de tradução?

Caimi: Ao traduzir a Crítica da razão pura me vi constrangido a elaborar uma teoria da tradução. Eu conhecia três caminhos diferentes para traduzir a Crítica. A primeira pessoa que traduziu a Crítica da razão pura foi Gottlob Born, que na quarta edição da obra traduziu-a para o latim. O trabalho que ele se propôs a fazer foi contar, revelar aos seus contemporâneos o que diz esse livro tão estranho. $\mathrm{O}$ mesmo fez José Del Perojo no final do séc.XIX e começo do séc.XX, o primeiro a traduzir a Crítica para o espanhol. Nesses casos, a tradução é simplesmente um recontar o que disse Kant na Critica, uma tarefa informativa. Esta era uma das possibilidades: informar o conteúdo. Outra possibilidade, que surgiu posteriormente, foi a de transplantar o que disse o autor, que foi o que fez o espanhol Garcia Morente - um magnífico escritor e tradutor - ao procurar reescrever a Crítica da razão pura em espanhol. Ele procurou reescrever todas aquelas palavras, como se fos- 
se um transplante, pegando a árvore que rendera frutos em alemão e transplantando-a para este solo novo, o espanhol. Esta tarefa é terrível, dificílima. Eu pensei que não poderia apenas indicar o que está dito, já que hoje todos dispõem daquela informação. Pensei também que não sou tão genial escritor a ponto de poder transplantar a árvore alemã para o solo espanhol.

Decidi, então, trabalhar como o restaurador ou copista do quadro ou obra de arte. Quando cai um pedaço do quadro, por exemplo, uma parte do olho da menina pintada por Vermeer, o restaurador não pintará o olho novamente como fez o autor original, o que seria impossível, já que ele não é o próprio Vermeer. Ele apenas acrescentará uma indicação "aqui havia um olho". Alguns restauradores fazem isso utilizando a cor cinza, para que se veja que aquele trabalho não é o trabalho de Vermeer, mas o seu. Pensei que eu poderia trabalhar assim, dizendo verdadeiramente o que está na obra para aqueles que não podem ler em alemão, mas como um intermediário que não tem a ousadia de preencher o que falta, de resolver o que está difícil ou o que ele próprio, tradutor, não pôde compreender. Por essa razão, sempre indiquei as variantes ou dificuldades em notas de rodapé, de modo que o leitor sempre fique certo a respeito do que está no alemão e do que são acréscimos meus - indicando até mesmo, por vezes, aquilo que realmente não consegui compreender. Quando estava traduzindo a Crítica lidei com pelo menos nove traduções diferentes ao mesmo tempo, a de Valério Rohden, a da Calouste-Gulbenkian, a francesa de Tremesaygues e Pacaud, duas ou três versões alemãs diferentes (as edições alemãs às vezes diferem entre si), outras edições espanholas mais antigas, a inglesa de Guyer e Wood e a latina de Born. A cada frase que fazia eu controlava, conferia com as demais traduções, para que pudesse saber o que podia ser escrito com certeza. Nem sempre era eu que dizia algo com certeza, por vezes usava Valério Rohden, Tremesaygues e Pacaud e outros para que me socorressem onde me restavam dúvidas.

CFA: Em sua tradução da Crítica da razão pura nota-se uma preferência pela fidelidade ao texto original, bem como uma tentativa de uniformização de vocabulário (por exemplo ao optar por tra- 
duzir Beziehung por "referência", de modo a manter "relação" para Verhältnis). O senhor diria que a tentativa de uniformização do vocabulário é uma das suas opções metodológicas de tradução?

Caimi: Pelo contrário: penso que isto é até mesmo um erro. Não se pode manter sempre, rigidamente, a correspondência entre a palavra alemã e uma mesma palavra em outra língua, porque às vezes o campo semântico de uma palavra em uma língua é diferente do campo semântico em outra. É preferível manter-se flexível, guardando mais fidelidade ao conteúdo do que à palavra. Seria até um erro manter sempre, rigidamente, uma dada opção. Por exemplo: o dicionário explica a palavra alemã angeblich como correspondendo àquilo que é fictício, mas se apresenta enganosamente como se fosse verdadeiro. No entanto, no vocabulário kantiano a palavra corresponde textualmente à palavra latina dabile, isto é, aquilo que pode ser dado. Se optarmos por traduzi-la sempre como aquilo que se apresenta falsamente, teríamos uma dificuldade imensa.

CFA: Em um artigo compilado no livro Crítica da razão tradutora: sobre a dificuldade de traduzir Kant, o senhor afirma: "Kant pensa em latim. Não que ele o faça sempre, mas sim que esse é o caso em passagens decisivas". Em que medida o pensar em latim de Kant facilita ou dificulta a tarefa de tradução dos textos kantianos para linguas neolatinas?

Caimi: Eu penso que facilita, mas não diretamente. $\mathrm{Na}$ medida em que não somos falantes nativos do alemão, temos a vantagem de não estarmos presos às coisas que seriam evidentes para o falante nativo. No caso do angeblich, o leitor alemão suporia tratarse de um termo que se refere àquilo que se apresenta como sendo verdadeiro, quando na verdade Kant tem em vista o termo dabile latino. Nós, que estamos de fora, podemos ter uma visão que, não sendo propriamente crítica, é ao menos de um certo estranhamento, o que nos leva a não tomar como evidentes coisas que não o são. Naturalmente, às vezes isso pode ser também uma desvantagem, como quando a estrutura latina se apresenta a nós como evidente e não nos perguntamos o que Kant visava ao utilizar-se dela. Quer dizer, às vezes isso facilita, outras vezes dificulta. $O$ trabalho de tradução é sempre infernal, nele não se pode relaxar jamais. 
CFA: O senhor destacaria um ou mais conceitos da flosofia kantiana particularmente dificeis de traduzir?

Caimi: Sim: Gemüt. Lembro que há um trabalho de Valério Rohden sobre a tradução de Gemüt. Eu tomei a decisão de traduzir por "mente", o que me parece correto na maioria das vezes, embora haja outras em que faz mais sentido traduzir por "ânimo". Kant usa as duas equivalências latinas e há inclusive passagens em que ele próprio afirma que Gemüt quer dizer mens ou animus.

$\mathrm{Na}$ Critica da faculdade do juizo há um conceito central que é verdadeiramente intraduzível: Zweckmässigkeit. Não sei como traduzi-lo. Compreendemos muito claramente o que ele quer dizer, mas não temos uma palavra pra traduzi-lo. As traduções dessa expressão com perífrases são sempre incompletas. "Conformidade a fins”, por exemplo, por mais que seja uma opção correta, não dá conta de todo o conceito, porque ele se refere não apenas à finalidade, mas também aquilo que se quer dizer quando se afirma que algo tem sentido (dentro de um contexto). "Isso não tem sentido!" - Kant diria "Das ist nicht zweckmässig!".

CFA: E para Bestimmung? Qual foi a sua opção?

Caimi: A escolha foi automática: "determinação".

CFA: Mas e no contexto da filosofia prática, onde Kant fala em uma Bestimmung des Menschen numa acepção que remete à vocatio latina?

Caimi: É verdade. Eis aí outro caso em que não se pode manter uma fidelidade total a uma dada opção, mas é preciso levar em conta o contexto.

CFA: E para Gesinnung? O senhor tem alguma opção feita?

Caimi: Este é também um termo tradicionalmente difícil de traduzir. "Disposição interior", "intenção", não sei ao certo. Este é um termo difícil.

CFA: O senhor foi professor convidado na Universidade de Paris I, na Universidade de Eichstätt e na Universidade de Compostela. Como o 
senhor definiria as suas relaçôes acadêmicas com esses países europeus e suas universidades?

Caimi: Infelizmente, a relação é menos institucional e mais a conseqüência de convites que decorrem de nós, kantianos, nos conhecermos pessoalmente. O professor de Eichstätt que me convidou trabalhou antes como assistente do professor Funke, na época em que fiz meu doutorado na Alemanha. Ele veio a Buenos Aires a meu convite e depois me convidou para uma estadia em sua universidade. Tenho uma relação estreita e muito ativa com a Sociedade Kant de Trier e Mainz. Mantenho com eles um intercâmbio permanente, participo da comissão de avaliação da KantStudien, entre outras atividades.

CFA: O senhor também foi professor convidado em diferentes universidades latino-americanas, tais como a Universidade Simón Bolivar (Caracas, Venezuela), a Universidade Federal do Rio Grande do Sul (Porto Alegre, Brasil), a Universidade de Campinas (Campinas, Brasil) e a Universidade do Rio Grande do Norte (Natal, Brasil). Como o senhor definiria as relaçóes acadêmicas entre os países da América latina? E as suas relaçôes acadêmicas com esses paises e universidades?

Caimi: Como eu disse anteriormente, não posso afirmar que haja relações institucionais entre a Universidade de Buenos Aires e essas outras instituições nas quais fui professor convidado. Eu não tenho apoio institucional da Universidade para convidar outros pesquisadores. Quando venho ao Brasil, são as diferentes universidades que me convidam. É claro que diferentes professores me conhecem, em especial os kantianos, mas o convite é sempre feito pelas próprias universidades, são elas quem arcam com todos os custos, etc. Isso torna tudo mais fácil, a organização é perfeita, me sinto bem vindo trabalhar aqui. Mas não posso dizer o mesmo em relação à Universidade de Buenos Aires. Tenho sempre um medo bem fundado de que eu convide um professor e, no último momento, a Universidade diga que o dinheiro já foi gasto com outra coisa e que não poderemos arcar com os custos desse professor. Portanto, não posso dizer que haja uma relação institucional. De minha parte, a relação é sempre pessoal. 
CFA: O senhor é pesquisador do Conicet (Consejo Nacional de Investigaciones Cientificas y Técnicas). Como avalia a situação do financiamento à pesquisa acadêmica na Argentina hoje?

Caimi: Sou pesquisador vitalício do Conicet. Nisso o Conicet é diferente de instituições brasileiras como o $\mathrm{CNPq}$, porque não preciso renovar minha participação como pesquisador a cada dois anos. Isto é muito melhor para o pesquisador, muito mais seguro e estável. No Brasil, o pesquisador fica sempre na dependência do término de seu projeto. Isto com relação ao financiamento dos pesquisadores. Mas, com relação à Universidade, a instituição no Brasil é muito mais forte e diversificada. No Brasil há pelo menos cinco grandes universidades, prestigiosas. $\mathrm{Na}$ Argentina há somente uma, talvez duas. No Brasil o ambiente universitário é muito mais vivo, os professores podem mudar de universidade, fazer concursos. A Universidade de Buenos Aires é o teto que se pode alcançar, e depois não há mais nada.

CFA: Voltamos ao assunto de sua participação nas sociedades kantianas. No último congresso da Kant-Gesellschaft iniciaram-se articulaçôes visando à formação de uma Sociedade Kant Ibero-americana, que reunirá pesquisadores de países europeus e americanos falantes da lingua espanhola. Como tem sido o processo de constituição da sociedade Ibero-americana e como o senhor avalia ofortalecimento das sociedades de estudo e pesquisa sobre Kant?

Caimi: $\mathrm{Na}$ verdade, era estranho que não houvesse uma Sociedade Kant de língua espanhola. Penso que não se possa fazêla em Buenos Aires por conta daquilo que eu comentava sobre não haver apoio suficiente por parte da Universidade. Os estudantes que trabalham comigo, meus assistentes na disciplina, são incrivelmente inteligentes e têm grande força de ação - o que já não tenho. Certo tempo atrás, eles fundaram um centro de estudos kantianos em Buenos Aires, que agora integra a Sociedade Kant de língua espanhola.

Penso que estas são coisas positivas, ainda que a pesquisa se faça em última instância na solidão, pois é uma questão pessoal. A inteligência é aquele sopro do espírito e não depende de nenhuma associação ou sociedade, embora, naturalmente, haja sempre 
mais estímulo quando estamos trabalhando juntos. Por isso penso também que é importante que se façam laços com a Sociedade Kant Brasileira. Há aqui um desenvolvimento extraordinário da pesquisa kantiana, que foi crescendo em qualidade e de maneira velocíssima. Os Cadernos de Filosofia Alemã são um bom exemplo disso. $\mathrm{O}$ que se faz aqui hoje é inclusive melhor do que o que se faz em outros países ditos desenvolvidos.

Há poucos anos, logo após o X Congresso Kant, em São Paulo, o professor Fred Rauscher, dos Estados Unidos, disse ser magnífico o que se está fazendo no Brasil e contou-me que estava organizando uma tradução de dez trabalhos que foram recomendados como alguns dos melhores trabalhos kantianos escritos em português do Brasil.

CFA: E o que significou para o senhor receber o prêmio da Kant-Gesellschaft?

Caimi: O prêmio significou muito para mim, e em muitos níveis. De um lado, porque dediquei quase quarenta anos ao estudo de Kant, e ver que toda essa dedicação teve sentido foi um alívio. Isto foi muito bom. De outro, porque pude estar mais seguro de que minhas opiniões e interpretações têm algum respaldo. Não que eu não seja autocrítico, mas isso me deixou pelo menos um pouco mais seguro de mim mesmo. Não sei até que ponto, mas um pouco mais. Por fim, devo dizer também que foi para mim um grande prazer, uma emoção muito grande, foi muito bonito, uma cerimônia muito bonita.

CFA: Para concluir, gostariamos de perguntar quais são os próximos projetos intelectuais do senhor? Em particular com relação ao trabalho de tradução, o senhor tem algum próximo projeto em vista?

Caimi: Vou procurar não mais traduzir Kant. Traduzirei por prazer, porque traduzir também dá prazer, mas o farei sem grandes pretensões. Tenho um projeto imenso que é fazer um resumo do grande dicionário de Mellin, para o que montei uma pequena equipe, já que o dicionário é imenso, com onze volumes. Mellin era um contemporâneo de Kant que fez um trabalho maravilhoso, ele foi em seu tempo o melhor comentador de Kant. Talvez ainda 
o seja, embora muito poucos o conheçam. Mellin fez para cada um dos conceitos da filosofia kantiana uma pequena monografia, às vezes nem tão pequena - para o conceito de juízo de gosto, por exemplo, ele escreveu quase noventa páginas. Ele desenvolve todo o conceito, suas articulações internas e exemplos, explica bem o que ele quer dizer. São monografias maravilhosas sobre cada um dos conceitos, em onze volumes. Traduzir isso tudo seria uma tarefa impossível, por isso estamos fazendo um resumo. O projeto está quase acabado e deve ficar com em torno de quatrocentas e cinqüenta, quinhentas páginas, será um vocabulário de filosofia kantiana resumido de Mellin.

Estou também trabalhando, de maneira lenta, sobre o esquematismo. Estou desenvolvendo ideias que apresentei no último Congresso da Sociedade Internacional, em Pisa. 